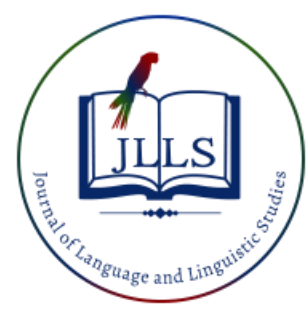

Available online at www.jlls.org

JOURNAL OF LANGUAGE AND LINGUISTIC STUDIES

ISSN: 1305-578X

Journal of Language and Linguistic Studies, 16(4), 2077-2096; 2020

\title{
The move structure of abstracts in applied linguistics research articles in light of the distribution and functions of metadiscourse markers
}

\author{
Zahra Ashofteh $^{\mathrm{a}}$ iD, Majid Elahi Shirvan ${ }^{\mathrm{b} 1}$ iD, Seyyed Ehsan Golparvar ${ }^{\mathrm{C}}$ \\ ${ }^{a}$ University of Bojnord, Bojnord, Iran \\ ${ }^{b}$ University of Bojnord, Bojnord, Iran \\ ${ }^{c}$ University of Bojnord, Bojnord, Iran
}

APA Citation:

Ashofteh, Z., Elahi Shirvan, M., \& Golparvar, S. E. (2020). The move structure of abstracts in applied linguistics research articles in light of thedistribution and functions of metadiscourse markers. Journal of Language and Linguistic Studies, 16(4), 2077-2096.

Submission Date:04/07/2020

Acceptance Date:19/07/2020

\begin{abstract}
To communicate with other experts in a specific field as well as sharing knowledge in the academic world, researchers might need to publish their research articles (RAs) in high-impact factor journals. In addition, to increase the possibility of publishing their RAs in these journals, they should improve their writing skills. Many investigations have been conducted so far which have analyzed the move structure or the distribution of metadiscourse markers in different sections of RAs. But, to the best of our knowledge, no study has yet been conducted to investigate the analysis of both move structure and use of metadiscourse markers in RAs abstracts of applied linguistics. To bridge this gap, the present study employed the model of abstract moves in RAs and the model of metadiscourse markers as a framework to analyze $125 \mathrm{RA}$ abstracts, which were extracted from five main journals. Regarding the move organizational features, presenting the research (PTR) and situating the research (STR) were identified as opening moves. Also, discussing the research (DTR), summarizing the findings (STF), and describing the methodology (DTM) were employed as closing moves. Furthermore, in terms of the distribution of metadiscourse markers in the collected abstracts, the findings showed the high frequency of transitions. In addition, the results demonstrated that applied linguistics authors are tentative and use more hedges in their abstracts, possibly to open space for opposite arguments of their claims. Finally, this study suggests pedagogical implications for novice authors in the field of applied linguistics.
\end{abstract}

(C) 2020 JLLS and the Authors - Published by JLLS.

Keywords: metadiscourse markers; distribution; function; Pho's model; Hyland's model; RA abstracts; applied linguistics

\section{Introduction}

In academic context, metadiscourse is the way by which authors project themselves into their discourse to express their commitments and attitudes toward the text and audience; therefore, one of the key characteristics of successful academic writing is the ability to know how to engage readers in specific disciplines by the deployment of metadiscourse markers (Hyland, 2004; Hyland \&Tse, 2005).

\footnotetext{
${ }^{1}$ Corresponding author. Tel.

E-mail address: elahishmajid@gmail.com
} 
One of the classifications of metadiscourse is based on Hallidayan systemic functional grammar (SFG) (Halliday, 1994). In this model, metadiscourse has three functions. The first one, using language to represent ideas and experiences, is referred to as ideational functions. The second, using language to express feelings, is called interpersonal function. Textual function as the third one concerns organizing language to fit in its context. Another classification of metadiscourse was proposed by Hyland(2004). In this established framework, interpersonal items are regarded as interactional metadiscourse whilemetatextualitems are categorized as interactive metadiscourse. Each of these two resources has some subcategories. Interactive resources consist of transitions, frame markers, endophorics, evidentials and code glosses whereas interactional metadiscourse involves boosters, hedges, attitude markers, selfmentions, and engagement markers.

With a previous study of Liu and Buckingham (2018) in mind, in this study we aimed to explore the schematic structure of metadiscourse markers in terms of their distribution and functions in each of the five moves of introduction, purpose, method, results, and discussion (IPMRD) of RA abstracts in the field of applied linguistics.

\subsection{Literature review}

Many investigations on metadiscourse have been done in different genres such as first-year university students' timed argumentative essays (Ho \& Li 2018),dentistry research reports(Crosthwaite, Cheung \&Jiang 2017), teacher feedback on student writing(Adel 2016) and in different disciplines such as applied Linguistics, biology, engineering, sociology,public administration, business studies and computer science(Hyland\& Jiang 2016, 2017, 2018; Hyland,2004) and in different sections of academic writing such as discussion section of research articles (Liu \& Buckingham, 2018), introduction of Ph.D. theses (Kawase, 2015, 2017), introductions of M.A. theses (Samraj, 2008), acknowledgements of dissertations (Chan, 2015) and research articles' abstracts (Jiang \& Hyland, 2016).

In former investigations of the schematic structure of different research article (RA) sections, researchers have indicated the existence of special metadiscourse markers while detecting moves (Khedri, Chan \& Ebrahimi, 2013; Yang \& Allison, 2003). This identification of the presence of metadiscourse markers and their functional contributions in different sections of RAs may be a logical reason for the identification of the interactive purpose of individual moves via the contribution of metadiscourse markers to the move structures of RA sections (Holmes, 1997).

The identified functions of metadiscourse markers entail the stance articulation and the direction of readers via the flow of information. Despite the previous studies conducted on metadiscourse features in different disciplines and different genres (Friginal \& Mustafa, 2017; Gillaerts \& Van de Velde 2010; Hu \& Cao, 2011; Jiang \& Hyland,2016; Khedri et al., 2013; Lores, 2004; Mocanu, 2015; Ozdemir \& Longo, 2014; Pho, 2008; Tanko, 2017), no study has yet been systematically conducted to investigate the metadiscourse distribution markers across moves in the abstracts of RAs, especially in the field of applied linguistics.

Awareness regarding the schematic structure of metadiscourse markers in the abstracts of applied linguistics RAs can contribute to the improvement of the academic writing skills of novice authors in the field. From the academic publishing perspective, the field of English for Academic Purposes (EAP) has recently targeted academic writing programs to provide academic writers with accurate English for the research publication process.

A decade ago, Flowerdew (2008) asserted that poor language might cause rejection of the submitted manuscripts to journals; thus, knowing about the style of disciplinary community in applied linguistics for researchers in the field is helpful. Consciousness-raising programs regarding the move structure of abstracts of RAs in the field ofapplied linguistics in terms of the contribution of metadiscourse markers 
can increase researchers' chances to publish their articles in well-established international journals by persuading journal editors to send their submitted manuscripts out for review as the schematic structure of abstracts of RAs might be initially considered by these editors in their review process.

In other words, in this study, the reason behind the focus on the abstracts of RAs in this field is that RA abstracts are an important genre in all disciplines and play a great role in attracting reviewers and readers (Jiang\& Hyland, 2016). From the readers' perspective, by initially running through the abstracts of RAs, readers can decide whether to take time and read the rest of the articles or not (Huckin, 2001).Therefore, academic writers' awareness regarding the schematic structure of metadiscourse markers in the abstracts of applied linguistics RAs can enable them to build appropriate genre-specific interactions with the readers of their articles in the field.Overall, we tried to find the answers to the following questions:

\subsection{Research questions}

1. What are the schematic organizational features of abstracts of applied linguistics RAs regarding the opening move, closing move, move frequency, move sequence, move cycle, and move embedding?

2. How are metadiscourse markers distributed across the different moves in applied linguistics RA abstracts?

3. What are the functions of metadiscourse markers in each moveof applied linguistics RA abstracts?

\section{Method}

\subsection{Corpus and data collection}

The corpus in this research consisted of 125 abstract sections from applied linguistics RAs which were randomly selected from five top peer-reviewedjournals in applied linguistics discipline. They were Applied Linguistics, Modern Language Journal, Studies in Second Language Acquisition, TESOL Quarterly, andLanguage Teaching Researchwhose 2018 impact factors according to journal citation reports were $3.225,2.789,2.702,2.256$, and 2.086 respectively.All articles were published during the last five years (2014-2018). The dataset in this research was not restricted to any specific type of research but included both qualitative and quantitative studies. The corpus contained 21894 words. The length of the abstracts in the corpus, including abstracts of the RAs ranged from 86 to 320 words, with an average length of 176 words.

Table 1. Descriptive statistics of abstract features

\begin{tabular}{ccccc}
\hline No. of abstracts & Total words & Mean length & Maximum length & Minimum length \\
\hline 125 & 21894 & 203 & 320 & 86 \\
\hline
\end{tabular}

Note. The unit for these categories is the number of words.

\subsection{Data analysis}

\subsubsection{Analysis of move structure}

This study followed Pho's (2008) model as a framework (see Table 2), in which PTR, DTM, and STF are considered as obligatory moves. Therefore, 11 articles from the journal of Applied Linguistics, two articles from Language Teaching Research, four articles from Modern Language Journal, and one 
article in TESOL Quarterly were removed due to the absence of three obligatory moves proposed by Pho.

We read all the sections of an article when we faced difficulties in the identification of abstract moves. Therefore, only $107 \mathrm{RA}$ abstracts were analyzed regarding the opening move, closing move, move frequency, move sequence, move cycles, and move embedding. Both bottom-up and top-down approaches were used to identify the moves of abstracts. In bottom-up approach move identification is based on specific linguistic signals; for example,the tense of the verbs, while in top-down approach, move classification is based on functions or interpretations of the content of the abstracts by focusing on contextual clues (Biber, Connor \& Upton, 2007; Upton \& Cohen, 2009).

Table 2. Move Structures of RA Abstract Sections (adopted from Santos, 1996; Pho, 2008)

\begin{tabular}{|c|c|c|}
\hline Moves & Function & Questionsasked \\
\hline $\begin{array}{l}\text { Move 1. Situating the } \\
\text { Research (STR)/Introduction }\end{array}$ & $\begin{array}{l}\text { Situating the research and indicating } \\
\text { the gap }\end{array}$ & $\begin{array}{l}\text { What has been known about } \\
\text { the field/topic of research? }\end{array}$ \\
\hline $\begin{array}{l}\text { Move 2. Presenting the } \\
\text { Research (PTR)/Purpose }\end{array}$ & $\begin{array}{l}\text { Presenting the research, hypothesis } \\
\text { raising, and indicating the purpose }\end{array}$ & What is the study about? \\
\hline $\begin{array}{l}\text { Move 3. Describing the } \\
\text { Methodology (DTM)/Method }\end{array}$ & $\begin{array}{l}\text { Providing information on design and } \\
\text { data analysis }\end{array}$ & How was the research done? \\
\hline $\begin{array}{l}\text { Move 4. Summarizing the } \\
\text { Findings (STF)/Results }\end{array}$ & $\begin{array}{l}\text { Presenting results and summarizing } \\
\text { main findings }\end{array}$ & What did the researcher find? \\
\hline $\begin{array}{l}\text { Move 5. Discussing the } \\
\text { Research (DTR)/Discussion }\end{array}$ & $\begin{array}{l}\text { Interpreting the implications of main } \\
\text { findings and recommendations for } \\
\text { future research }\end{array}$ & $\begin{array}{l}\text { What do the results mean? } \\
\text { So what? }\end{array}$ \\
\hline
\end{tabular}

\subsubsection{Analysis of metadiscourse markers}

Regarding the distribution of metadiscourse markers, in contrast with the move identification process, all RA abstracts, 125 in total,wereinvolved. Consistent with Hyland's (2005) interpersonal model of metadiscourse markers as a framework, all the abstracts were read and coded manually.

Metadiscourse markers in this study were analyzed from two phases. First, in the quantitative phase, we considered the total number of metadiscourse markers used in each move of the abstracts. Second, in the qualitative phase, the variation in the distribution of metadiscourse markers was investigated. Particularly, in the qualitative phase, we tried to find the possible reasons for the variation of metadiscourse markers in each moveand ascribe the variation to the nature of each move.

Table 3. Interactional metadiscourse (Hyland, 2005, p.49)

\begin{tabular}{lll}
\hline Metadiscourse & Functions & Examples \\
\hline Hedges & $\begin{array}{l}\text { Withhold commitment to a proposition and open } \\
\text { dialogue }\end{array}$ & Might/perhaps/possible/about \\
\hline boosters & Emphasize certainty or close dialogue & In fact/definitely/it is clear that \\
\hline Attitude markers & Express writers' attitude to proposition & Unfortunately/surprisingly \\
\hline
\end{tabular}




\begin{tabular}{lll}
\hline $\begin{array}{l}\text { Engagement } \\
\text { markers }\end{array}$ & $\begin{array}{l}\text { Explicitly build a relationship with the reader by } \\
\text { addressing to the reader }\end{array}$ & $\begin{array}{l}\text { Consider/note that/you can see } \\
\text { that }\end{array}$ \\
\hline Self-mention & Explicit reference to author(s) & I/we/my/our \\
\hline
\end{tabular}

Table 4. Interactive Metadiscourse (Hyland, 2005, p.49)

\begin{tabular}{lll}
\hline Metadiscourse & Functions & Examples \\
\hline Transitions & $\begin{array}{l}\text { Express semantic relation between main clauses or } \\
\text { sentences }\end{array}$ & In addition/but/and \\
\hline Frame markers & Refer to discourse acts, sequences or texts stages & Finally/my purpose is to \\
\hline $\begin{array}{l}\text { Endophoric } \\
\text { markers }\end{array}$ & Refer to information in other part of the text & Noted above/in section2 \\
\hline Evidentials & Refer to the sources of information from other text & $\begin{array}{l}\text { According to X/(Y, } \\
1990)\end{array}$ \\
\hline Code glosses & Help readers grasp meanings of ideational material & Namely/e.g/such as \\
\hline
\end{tabular}

\subsubsection{Reliability}

To strengthen the reliability of the analysis of move structure in the RA abstracts as well asthe distribution of the metadiscourse markers in each move, after a short interval ( 2 weeks),in thesecond round of data analysis, each researcher in this study re-analyzed the first data analysis to ensure intracoder reliability. It turned out to be $91 \%$. Regarding the inter-coder reliability, we compared the findings of our analysis and discussed any differences in our interpretations to reach consistency in the final analysis. The inter-coder reliability was $92 \%$, which was beyond the threshold of $90 \%$ suggested by Miles and Huberman (1994).The kappa statistic was used to test the inter-coder reliability.

\section{Results}

\subsection{Move organizational features}

The first and last sentences of abstracts are called the opening and closing sections which convey specific meanings (Can, Karabacak \& Qin, 2016). Twodifferent moves as opening moves and three different moves as closing moveswere identified in thecollected abstracts in this study. Table 5 illustrates the frequency and percentage of particular moves in the position of opening and closing parts of the abstracts. PTRis introduced as the most frequent move in the opening position of the abstracts $(\mathrm{N}=64 / 107)$, which occurred in nearly $60 \%$ of the whole abstracts. The high frequency of this move is due to the great role of the abstract section of RAs in persuading readers to read the whole article (Friginal \& Mustafa, 2017; Hyland, 2009).This is in line with the findings of Tseng's (2011) study. In addition,there is no STR in the majority $(\mathrm{N}=54 / 64)$ of the abstractswith PTR as theiropening move.This might be due to the brief nature of the abstracts.

As seen in the following example, the abstract opens with PTR and is followed by STF, DTM, STF, and DTR. Written with no STR, the authorfocuses more on a persuasive function of abstracts rather than an informative one (Can et al., 2016).

\section{Example 1.}


This article argues for a reconceptualization of the concept of 'corrective feedback' for the investigation of correction practices in everyday second language (L2) interaction ('in the wild') (PTR). Expanding the dataset for 22 research as suggested by Firth and Wagner (1997) to include interactions from the wild has consequences for the traditional concept of corrective feedback,(STF) which comes from classroom dyads of native speakers and nonnative speakers and focuses on a native speaker's correction of a linguistic error in an L2 speaker's turn(DTM). Correction practices in the wild, however, are co-constructed and predominantly initiated by the L2 learner herself. The study also shows that explanation practices are initiated by the L2 speaker or otherwise occasioned and that they emerge following a lack of understanding on the part of the L2 speaker during a correction episode. The data reveal no examples of $L 2$ teaching in the wild as correction or explanation practices that are not occasioned, that is, they do not come 'out of the blue. '(STF) I will argue that L2 teaching practitioners might benefit from more awareness of the circumstances that occasion and sustain correction and explanation practices(DTR).

The next most frequently opening move in this dataset isSTR by which writers can provide their readers with adequate background information and also refer to the existing gap in the previous works.

This finding supports Hyland (2004), who maintained that authors in the field of soft knowledge tend to focus more on introducing the topic of their study rather than their methodology.

In sum, following Hyland (2004), due to the nature of the opening section of the abstracts, both STR and PTR are dominant and no other moves were identified in the opening of the abstracts.

Table 5. Distribution of Opening and Closing Moves

\begin{tabular}{lcc}
\hline Moves & Opening move & Closing move \\
\hline STR & $43(40.2 \%)^{*}$ & $0(0 \%)$ \\
\hline PTR & $64(59.8 \%)$ & $0(0 \%)$ \\
\hline DTM & $0(0 \%)$ & $2(1.8 \%)$ \\
\hline SRF & $0(0 \%)$ & $46(43 \%)$ \\
\hline DTR & $0(0 \%)$ & $59(55.2 \%)$ \\
\hline Total & 107 & 107 \\
\hline
\end{tabular}

* Percentages have been rounded to one decimal point.

Table 6 shows the distribution of opening moves in different RA abstracts. For instance, in Language Teaching Research 15 out of 23 abstracts tended to open with STR; on the other hand, in the other four journals, there is a tendency for the abstracts to begin with PTR.

According to Table 6, 15 out of 24 abstracts extracted from TESOL Quarterly tended to have PTR as their opening move. In addition, Language Teaching Research is the only journal in this corpus whose abstracts opened more with STR rather than PTR. 
Table 6. Distribution of Opening Move across RA Abstracts

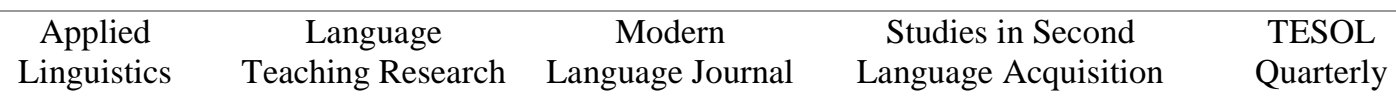

\begin{tabular}{cccccc}
\hline STR & $4(28.5 \%)^{*}$ & $15(65.2 \%)$ & $8(38 \%)$ & $7(28 \%)$ & $9(37.5 \%)$ \\
\hline PTR & $10(71.5 \%)$ & $8(34.8 \%)$ & $13(62 \%)$ & $18(72 \%)$ & $15(62.5 \%)$ \\
\hline Total & 14 & 23 & 21 & 25 & 24
\end{tabular}

* Percentages have been rounded to one decimal point.

Regarding the closing section of the abstracts, three different types of moves were identified: DTR, STF, DTM. The findings indicated that about $55 \%$ of the abstracts areclosed with DTR, $43 \%$ with STF and $2 \%$ with DTM. In contrast to DTM, which are employed less frequently than the other two moves (2/107), DTR and STF are used in 59 and 46 abstracts, out of 107 abstracts, respectively, which help writers in summarizing their results, suggesting for further research, and the implications of their findings in the closing section of the abstracts.

Table 7 shows the variation in the frequency and percentage of closing movesacross the RA abstracts. Unlike Studies in Second Language Acquisition, which 52\% of the abstracts have STF as the closing move, in four other journals, the abstracts end more with DTR as a closing move rather than STF.

Table 7. Distribution of Closing Moves across RA abstracts

\begin{tabular}{|c|c|c|c|c|}
\hline $\begin{array}{l}\text { Applied } \\
\text { Linguistics }\end{array}$ & $\begin{array}{c}\text { Language } \\
\text { Teaching Research }\end{array}$ & $\begin{array}{c}\text { Modern } \\
\text { Language } \\
\text { Journal }\end{array}$ & $\begin{array}{c}\text { Studies in Second } \\
\text { Language Acquisition }\end{array}$ & $\begin{array}{l}\text { TESOL } \\
\text { Quarterly }\end{array}$ \\
\hline
\end{tabular}

\begin{tabular}{lccccc}
\hline DTM & $1(7.1 \%)$ & $1(4.3 \%)$ & $0(0 \%)$ & $0(0 \%)$ & $0(0 \%)$ \\
\hline STF & $5(35.7 \%)$ & $10(43.5 \%)$ & $9(42.9 \%)$ & $13(52 \%)$ & $9(37.5 \%)$ \\
\hline DTR & $8(57.2 \%)$ & $12(52.2 \%)$ & $12(57.1 \%)$ & $12(48 \%)$ & $15(62.5 \%)$ \\
\hline Total & 14 & 23 & 21 & 25 & 24 \\
\hline
\end{tabular}

* Percentages have been rounded to one decimal point.

\subsection{Move frequency}

The frequency of single moves, the percentage of each individual moveout of the total number of moves, and the average frequency of each individual move per each RA abstract section are shown in Table 8. The most frequent move is PTR, which appears on average 1.27 occasions per each RA abstract section. The next frequent moves are STF and DTM which involve $24 \%$ and $23.4 \%$ of all moveoccurrences respectively. STR with 54 occurrences and DTR with 68 occurrences are the least frequent moves in this corpus. 
Table 8. Distribution of Moves in RA Abstracts

\begin{tabular}{lccc}
\hline Moves & Total & Percentage* & Average Freq. per section \\
\hline Situating the research (STR) & 54 & $11 \%$ & 0.5 \\
\hline Presenting the research (PTR) & 136 & $27.6 \%$ & 1.27 \\
\hline Describing the methodology (DTM) & 115 & $23.4 \%$ & 1.07 \\
\hline Summarizing the findings (STF) & 118 & $24 \%$ & 1.1 \\
\hline Discussing the research (DTR) & 68 & $14 \%$ & 0.63 \\
\hline
\end{tabular}

* Percentages have been rounded to one decimal point.

As seen in Table 9, the most frequent move in all five journals is PTR. Although the next most frequent move in abstracts of Applied Linguistics, Studies in Second Language Acquisition and TESOL Quarterly is STF, DTM is the next most frequent move in RA abstracts of both Language Teaching Research and Modern Language Journal.

Table 9. Distribution of Five Moves across journals

\begin{tabular}{lccccc}
\hline & $\begin{array}{c}\text { Applied } \\
\text { Linguistics }\end{array}$ & $\begin{array}{c}\text { Language } \\
\text { Teaching } \\
\text { Research }\end{array}$ & $\begin{array}{c}\text { The Modern } \\
\text { Language Journal }\end{array}$ & $\begin{array}{c}\text { Studies in Second } \\
\text { Language Acquisition }\end{array}$ & $\begin{array}{c}\text { TESOL } \\
\text { Quarterly }\end{array}$ \\
\hline STR & $5(6.9 \%)$ & $17(15.9 \%)$ & $9(9.7 \%)$ & $12(11.2 \%)$ & $11(9.8 \%)$ \\
\hline PTR & $21(29.2 \%)$ & $30(28 \%)$ & $25(26.9 \%)$ & $28(26.2 \%)$ & $32(28.6 \%)$ \\
\hline DTM & $16(22.2 \%)$ & $24(22.4 \%)$ & $24(25.8 \%)$ & $26(24.3 \%)$ & $25(22.3 \%)$ \\
\hline STF & $18(25 \%)$ & $23(21.5 \%)$ & $23(24.7 \%)$ & $27(25.2 \%)$ & $27(24.1 \%)$ \\
\hline DTR & $12(16.7 \%)$ & $13(12.2 \%)$ & $12(12.9 \%)$ & $14(13.1 \%)$ & $17(15.2 \%)$ \\
\hline Total & 72 & 107 & 93 & 107 & 112 \\
\hline
\end{tabular}

* Percentages have been rounded to one decimal point.

\subsection{Move sequences}

The sequential occurrence of moves or the analysis of a typical order of move is called a move sequence (Tanko, 2017). The most frequent move sequence in the RA abstracts of the five journals in this study was DTM-STF. The next most frequent move sequences were PTR-DTM, STF-DTR, and STF-DTR respectively. Table 10demonstrates the number of each of the three most frequent move sequences in all the RA abstracts and also compares the frequency of each move in each sequence with their frequency as an individual move when is not part of a sequence. 
Table 10. Move Sequence Frequency in the RA Abstracts

\begin{tabular}{lc}
\hline Move sequence & Frequency \\
\hline PTR - DTM & 103 \\
\hline DTM - STF & 93 \\
\hline DTM (in a sequence) & $111(96.5 \%)^{*}$ \\
& \\
PTR (in a sequence) & $93(75.7 \%)$ \\
\hline STF (in a sequence) & \\
\hline
\end{tabular}

*Percentages have been rounded to one decimal point.

As seen in Table 10, nearly $96 \%$ of the occurrences of DTM in the corpuswerein sequence either with PTR or STF (see example 2 and 3).Only 3.5\% of the occurrences of DTMwere neither with PTR nor STF in a sequence.

\section{Example 2}

DTM-PTR: Explicit phonetics instruction can help second language (L2) learners to moderately improve their pronunciation, but less is known about how the instruction affects learners' perception, even though there is evidence that perception and pronunciation are related (STR). This study provided phonetics instruction to students $(n=46)$ studying Spanish as a foreign language (PTR) and measured the resulting change in their perception of eight target phones as compared with a control group $(n=41)$. Perception was assessed with discrimination tests immediately following instruction and three weeks later (DTM). Results indicated that the instruction conferred a small advantage in the delayed post-test and that course level was not a significant factor (STF), suggesting that phonetics instruction was effective for attuning the perception of learners at multiple stages of development (DTR).(Language Teaching Research, 2015)

\section{Example 3}

DTM - STF:This paper provides a comprehensive overview of lexicogrammatical markers of important lecture points and proposes a classification in terms of their interactive and textual orientation (PTR).The importance markers were extracted from the British Academic Spoken English corpus using corpus-driven and corpus-based methods. The classification is based on the markers' constituents and context(DTM). Most markers are interactively oriented towards the content (e.g. the point is) or listeners (e.g. you should remember) rather than the speaker (e.g. I should stress) or speaker and listeners jointly (e.g. I want you to notice).Many content-oriented markers also have secondary listener orientation (e.g. these are the things to take home). As regards their textual orientation, markers typically occur before the highlighted point (STF). The analysis aims to reveal how the realizations of this metadiscursive feature reflect key characteristics of the lecture genre and suggests factors that may affect the efficacy of importance marking (PTR). The findings are useful for lecture listening and note-taking courses, lecturer training, and educational research assessing the efficacy of such discourse organizational cues (DTR).(Applied Linguistics, 2015)

\subsection{Move cycles}

The sequence of STR-PTR-DTM-STF-DTR is frequent in all the RA abstracts of the journals. For instance, in the journal of Applied Linguistics 6 out of 14, in Language Teaching Research 16 out of 23, the Modern Language Journal 15 out of 21, Studies in Second Language Acquisition 17 out of 25, and TESOL Quarterly 12 out of 24 abstracts follow this sequence. Generally, 60\% of the RA abstracts in this corpus followthis pattern and the others followdifferent sequences. Seven abstracts have cyclical patterns. For instance, in example 4, the sequence STR-PTR occurs twice. 


\section{Example 4}

In critical period hypothesis (CPH) research, native speaker (NS) norm groups have often been used to determine whether nonnative speakers (NNSS) were able to score within the NS range of scores (STR). One goal of this article is to investigate what NS samples were used in previous $C P H$ research (PTR). The literature review shows that $N S$ control groups tend to be small and highly educated and that detailed background information is usually not provided (STR). Another goal of this article is to investigate how the NS norm group may affect the incidence of nativelike performance by NNSS(PTR). To this end, 124 NSs and 118 NNSS of Dutch completed five comprehension tasks and a vocabulary task (DTM). The results also showed that, insofar as there were effects of frequency, norms based on low-frequency test items tended to be more inclusive(STF). The results imply that the selection of NSs in CPH research deserves more consideration than it has(DTR).(Studies in Second Language Acquisition, 2014)

\subsection{Move embedding}

Merging two or more than two moves in one sentence is called move embedding (Pho, 2008). Although most of the moves in the RA abstracts of this study appeared in a sentence or serial sentences or clauses (either finite or non-finite clause), there were some cases in whichmoves were realized in the form of a phrase which can be attributed to the abbreviated nature of RA abstracts.

All of the move embeddings in the corpus occurred with DTM. Among 14 embedded moves, ten of them embedded DTM in PTR(example 5) and four of them embedded in STF (example 6).

\section{Example 5}

The present study investigates events in an English language classroom at a Nepalese public college, (PTR) using ethnographic observations and interviews (DTM).(Language Teaching Research, 2014)

\section{Example 6}

The dimensions of flow, as they emerged in the data, were identified (STF) via a content analysis of 208 diary entries (DTM).(TESOL Quarterly, 2017)

Authors write a subordinate clause which followed by the main clause to show the information in the main clause more important than a subordinate clause. This is a strategic choice to attract busy readers' attention (Santos, 1996).

\subsection{Metadiscourse markers in different moves}

\subsubsection{Interactive metadiscourse}

As Table 12 demonstrates transitions are recorded the highest frequency of use in all moves of abstracts except PTR. Transition markers are used to establish logical relations in the text so they help readers through the text. According to Table 11, there are three types of transition markers (Hyland, 2005, p. 50).The most frequent transition type in STR and STF is comparison type, (Example 7) while additive one is commonly used in PTR and DTM (Example 8). On the other hand, in DTR authors prefer to use consequential transitions(Example 9).

And is the most preferred type of additive transitions in each of the moves and but is the most common type of comparison transitions in all moves except STR.

\section{Example 7}

Explicit phonetics instruction can help second language (L2) learners to moderately improve their pronunciation, $\underline{\boldsymbol{b u t}}$ less is known about how the instruction affects learners' perception, even though there is evidence that perception and pronunciation are related.(STR, Language Teaching Research 2015)

\section{Example 8}

All learner talk was audio recorded, transcribed and analyzed for the quantity, type and resolution of language related episodes (LREs) as well as the patterns of dyadic interaction. Furthermore, the study examined the texts produced using both quantitative and qualitative measures. (DTM, Language Teaching Research 2017)

\section{Example 9}

The finding is significant because this is the first L2 study to find the superiority of expanding over equal spacing.(DTR, Studies in Second Language Acquisition 2015) 
Table 11. Distribution of different types of transition

\begin{tabular}{lccc}
\hline & addition & comparison & consequence \\
\hline STR & 9 & 26 & 2 \\
\hline PTR & 13 & 2 & 2 \\
\hline DTM & 14 & 5 & 1 \\
\hline STF & 24 & 36 & 4 \\
\hline DTR & 5 & 4 & 7 \\
\hline
\end{tabular}

Endophoric markers, which are used to point to the different parts of the same text, are the least frequent interactive metadiscourse markers in all moves. Such markers can be seen in the following example.

\section{Example 10}

Taking 1925, the founding year of Language, the journal of the Linguistics Society of America, as a benchmark for 'the past', and 2015 as benchmark for 'the present', the author considers what was known then and what is known now about second language acquisition in applied linguistics.(PTR, Applied Linguistics 2015)

The second most frequent interactive device in DTM, STF and DTR arecode glosses which help readers to understand the researchers' purposes deeply (Hyland, 2007)and also allow researchers toprovide methodological information (Example 11), data description (Kawase, 2015) or clarify sentences or one distinctive word.

\section{Example 11}

The researcher used a short story analytical approach to analyze her narratives. Short stories are excerpts of data extracted from a larger set of data such asconversations, interviews, written narratives, and multimodal digital stories. (DTM, TESOL Quarterly 2016)

Evidentials, provide readers with references from other text, are the second frequent interactive metadiscourse markers in STR and PTR. Referring to different external sources that relate to the topic of the research, authors seek to assert gapsand insufficiencies in previous works (Example 12).

\section{Example 12}

Language aptitude comprises cognitive and perceptual abilities that predispose individuals to learn well or rapidly (Carroll 1981; Doughty et al. 2007) and that can interplay with age by moderating its effects on learning outcomes...findings have been mixed regarding its role in child second language acquisition (e.g. AbrahamssonandHyltenstam 2008 vs. DeKeyser 2000). (STR, Applied Linguistics 2014)

Frame markers are less frequent in STR and DTR while they are commonly used in PTR, DTM, and STF(Example 13). They enable authors to have a sequential organization of the study and guide readers.

\section{Example 13}

First, it is argued that the identification of words of high, low, and statistically significant frequency can help in the identification and exploration of language ideologies within corpora ... Secondly, collocation data can aid researchers in gaining greater insight into the ways in which languages are being represented... Finally, the use of dispersion plots can help researchers to identify sites with high-and low-frequency items for closer analysis.(STF, Applied Linguistics 2017) 
Table 12. Distribution of interactive metadiscourse across each move

\begin{tabular}{lccccc}
\hline Moves & Transitions & $\begin{array}{l}\text { Frame } \\
\text { markers }\end{array}$ & $\begin{array}{l}\text { Endophoric } \\
\text { markers }\end{array}$ & Evidentials & $\begin{array}{c}\text { Code } \\
\text { glosses }\end{array}$ \\
\hline $\begin{array}{l}\text { Introduction (3142 } \\
\text { words) }\end{array}$ & 38 & 2 & 0 & 19 & 5 \\
\hline Purpose (4918 words) & 24 & 8 & 3 & 15 & 6 \\
\hline Method (5088 words) & 23 & 16 & 1 & 8 & 34 \\
\hline Result (6630 words) & 82 & 8 & 0 & 2 & 5 \\
\hline Discussion (2116 words) & 18 & 2 & & 14 & 20 \\
\hline
\end{tabular}

\subsubsection{Interactional metadiscourse}

As Table 13shows, except DTM, hedges are reported as the most frequent interactional devices in all moves of abstract. As seen in example 14, the author tries to show the provisional nature of his study by using hedges and opens space for further revisions. In fact, by the use of hedges, the author triesto ascertain uncertainty in his statements and make his arguments more persuasive.

\section{Example 14}

The results also showed that, insofar as there were effects of frequency, norms based on low-frequency test items tended to be more inclusive. (STF, Studies in Second Language Acquisition 2014)

Attitude markers, by which writers express his attitude toward the text, are the second most frequent in STR, STF and DTR. 9 out of 14 attitude markers used in STR, 8 out of 15 in STF and only 1 out of 4 in DTR refers to the importance of the study or topic. Other attitude markers used to show writers' interest in the text.

\section{Example 15}

Directly linked to the Common European Framework of Reference for Languages (Council of Europe, 2001) proficiency guidelines, it is designed to achieve an ambitious dual goal: document students' skills and foster selfregulated learners. The question remains whether the ELP accomplishes its desired effect. (STR, Modern Language Journal 2014).

Employing attitude markers, the authors show the importance of the topic (example 15) or demonstrate their positive attitude towards the text (example 16).

\section{Example 16}

These results are consistent with MG, the representation model proposed by Amaral and Roeper (2014), because an acquisition path can be described using simple rules with lexical or pragmatic restrictions, which may be targetlike. Optionality can be explained considering that L1 and L2 rules coexist and are never deleted, simply assigned different productivity levels or blocked. (DTR, Studies in Second Language Acquisition 2018)

Engagement markers, which help the writer to attract readers' attention by directly addressing them (Hyland \& Jiang, 2018) use less frequently among all moves. As Table 13 demonstrates only one engagement marker in each of STR, PTR and STF move and two engagement markers in DTM and DTR were used. See the following example. 


\section{Example 17}

Upper-intermediate L2 German learners were flooded with spoken exemplars of a difficult morphological structure, namely strong, vowel-changing verbs. Toward the end of exposure, the mandatory vowel change was omitted, yielding ungrammatical verb forms (compare Leung \& Williams, 2012). (DTM, Studies in Second Language Acquisition 2016)

Table 13. Distribution of interactional metadiscourse across each move

\begin{tabular}{lccccc}
\hline Moves & Hedges & Boosters & Attitude markers & Engagement markers & Self-mentions \\
\hline STR(3142 words) & 28 & 8 & 14 & 1 & 0 \\
\hline PTR (4918 words) & 18 & 3 & 3 & 1 & 14 \\
\hline DTM(5088 words) & 3 & 1 & 1 & 1 & 3 \\
\hline STF (6630 words) & 54 & 8 & 15 & 2 & 3 \\
\hline DTR(2116 words) & 45 & 3 & 4 & & 2 \\
\hline
\end{tabular}

As Hyland (2001) asserted, authors of RAs use self-mention for diverse functions such asstating the purpose of the article, summarizing the procedures, and claiming a scientific finding or interpretation.

Self-mentions are the second frequent interactional metadiscourse markers in PTR by which the writer providesanauthorial stance.Self-mentions are used in their subject forms, and possessive forms while non-reflexiveforms of self-mention can also be found.

Using first person pronouns, the authors portray themselves not only as an agent of the research but also as a person who makes a scientific claim(Samraj, 2008).As an exampleofthis fact; see Example 18, where the author adopts a more visible presence by using self-mentions.

\section{Example 18}

In this article $\underline{I}$ argue for the establishment of 'Applied Linguistic Historiography' (ALH). Considering issues of rationale, scope, and methods in turn, $\underline{\boldsymbol{I}}$ provide reasons why ALH is needed and argue that, while it can borrow from Linguistic Historiography, it should also distinguish itself. (PTR, Applied Linguistics 2016)

Boosters are the third frequent metadiscourse markers in STR and STF by which authors strengthen their claims. In the example below, the author usesan impersonal source of information to distance himself from the statement and decrease his responsibility for the statements.Furthermore, he strengthenshisclaim by employing the underlined booster.

\section{Example 19}

It is argued that the concept of aptitude needs to be updated, and that clear linkages to second language acquisition processes need to be established. (STF, Applied Linguistics 2015)

Attributing the agency to inanimate subjects such asthe findings and results, the authors remove any human intervention in their academic claim-making and emphasize the objectivity of construction.

\section{Example 20}

The results demonstrate that spoken and written modalities are influenced differently by anxiety with the impact of output anxiety being significantly stronger in speech than in writing. (STF, Applied Linguistics 2016) 


\section{Discussion}

\subsection{Move organizational features}

As the results show,the RA abstracts in TESOL Quarterly tended to be closed with DTRrather than theother moves. This finding is in accordance with Tseng's(2011) study, in which he analyzed 90 RA abstracts inthree journals in the field of applied linguistics. In contrast with Tseng's(2011) study, in the present study, RA abstracts of TESOL Quarterly contain STR more than those of the otherjournals of applied linguistics while DTR is more frequent in all the abstracts of the selected journals in this field. Although Table 7 shows that the frequency of DTR, as a closing move in TESOL Quarterly, is more than that of the abstracts in the journal of Applied Linguistics, generally, DTR is used more frequently inthe abstracts of the journal of Applied Linguistics than TESOL Quarterly. This finding is justifiable when SFTis used after the DTR.

Regarding move frequency, all the 25 abstracts in the Journal of Studies in Second Language Acquisition, 24 abstracts in TESOL Quarterly, 23 abstracts in Language Teaching Research, and 22 ones in Modern language Journal contain STF, whereas only 14 abstracts in Applied Linguistics contained STF. This obvious variation can be attributed to the fact that most of the articles involved in those four journals are empirical studies. As a result,STFseems to be an essential part of these kinds of studies while theoretical studies, which are common in the field of applied linguistics, due to their theoretical nature does not present the results or discussions in their abstracts (Pho, 2008).

The fact that all of the move embedding in this corpus occurred with DTM, especially within PTR and STF, is in line with Pho's (2008) finding thatDTM was the most frequent embedded move in his study due to its variety in forms. In other words, as supported by the findings of this study, there are many structural representations by which researchers can describe the method of their study in the abstract section of their RAs. For example, DTM can occur in sentences as a noun phrase, verb phrase, or gerund phrase.

\subsection{Metadisocurse markers in different individual moves}

\subsubsection{Interactive metadiscourse markers}

Regarding the use of metadiscourse markers except for DTR, generally interactive metadiscourse markers were used more frequently in the RA abstract than interactional metadiscourse markers in all of the moves. This might be due to the fact that interactive devices aim to organize the academic discourse and ensure writers that their intentions are received correctly by readers (Hyland \& Jiang, 2018).

Also, the most frequent interactive metadiscourse markers in all the moves of RA abstracts were transitions; this is in line with Hyland and Jiang's (2018) findings. Furthermore, this great use of transitions and identifying it as the most frequent type of interactive metadiscourseis inconsistent with Ozdemirand Longo's (2014) analysis of metadiscourse markers in Turkish and USA postgraduate students' MA thesis abstracts written in English.Transitions seek to establish logical relations between sentences and help writers to persuade readers (Ho \& Li, 2018:Hyland, 2005).

In particular, comparison transitions were used more frequently in STR than the other moves in the RA abstracts. It can be attributed to the mentioning of, and comparing the previously related findings, in each abstract to refer to the superiority of the achieved findings to the previous ones and find the gap in this move. In terms of the types, the most common type of transition in DTRwasconsequencemarker. This could be explained by the major role of this move as the final move, in which authors discuss the findings. As a result, they should achieve a comprehensible interpretation. Therefore, employing consequence transitions in this move tended to be justifiable. It should be mentioned that the highly 
frequent use of and, as the most common type of addition marker, andbut, as the most preferred comparison transition marker in the RA abstracts, can be due to their ease of use and simplicity in structure (Ho \& Li, 2018).

On the other hand, the high proportion of evidentials in STR and PTR in the move structure of the RA abstracts can be attributed to the essentiality of authenticity, so the more external references the articles involve, the more authentic they are.Using evidential; that is, referring to the previous studies in the PTR and STR,enables the authors of the abstracts to show the claim of the pioneer scholars or the origin of an argument as well as the relation of the previous studies, in terms of their aims and findings, to the current study(Hyland, 2005).

Another possible reason for this high frequency of evidentials, especially in STR can be ascribed to the increasing number of research in this field and the need to reviewing all those literature.

In addition, the authors of the abstracts can demonstratethe importance of a given topic by establishing the scope of that topic by mentioning the previous research conducted on that topic.

The second highly occurring interactive metadiscourse markers in DTM and STF are code glosses. Thiswas expected because as mentioned before code glosses help writers to clarify meanings; thus, it is essential to use code glosses to clarifythe technical words or the process of research in a given study.The low frequency of code glosses in STR, PTR, and DTR might suggest that authors in these moves didnot use any terms which needed extra explanation, exemplification or reformulation.

Researchers should describe the process of data collection, data analysis in DTM. To do this end, they employ frame markers by which they can segment different parts of research processes in a sequence and guide readers through the process of reading. That is why frame markers were used more frequently in DTM than other moves.

\subsubsection{Interactional metadiscourse markers}

Hedges are the most frequent interactive metadiscourse markers in all the moves of the RA abstracts. This great use of hedges shows the consciousness of the authors in this field regarding its function as opening space for future opposite arguments from other researchers in the same field. Authors need to anticipate different viewpoints from different readers regarding a specific argument and the possible ways future studies might react to that argument. By doing this, authors use hedgestoassure the acceptance of the argument for the readers of the abstracts (Hyland \&Jiang, 2018). In other words, via the use of hedges in the RA abstracts, the authors present their findings in a temporary state to open space for future negotiation of their findings and show their politeness by saving the negative face of the researchers of the previous studies whose findings and arguments were different from theirs.

The large proportion of attitude markers in STR and STF of the RA abstractwas expected due to the persuasive nature of abstracts. Hyland (2005) contended that language which expresses the attitude of authors towards their text or readers can be more persuasive than the others. That is, using attitude markers can affect the abstracts' readers and bring them into an agreement with the propositions in STR and STF. Also, this high frequency of attitude markers in STFis congruent with Hyland and Jiang's (2016) findings that in order to have a professional and successful academic writing, authors should project their judgments towards their findings and comment on them. The fact that the most common type of attitude markers used in STR is related to the importance of the study can be attributed to the major role of this move in providing readers with the significance and novelty of the topic (Pho, 2008).

Compared to hedges and attitude markers, boosters were less frequent in RA abstracts. This might be due to the fact that applied linguistics as other sciences hasa provisional nature.Therefore, it might be better for the authors in this discipline to show low commitment to their propositions and respect the possible alternative voices regarding their findings in the abstracts; as a result, provide opportunities for 
them to challenge their interpretations.Furthermore, the prevalent use of verbs such as show, reveal, indicate, find, and demonstrateand low frequency of cognitive verbs such assuggest, think, believeand knowin STFindicate the tendency towards objectivity in the presentation of the findings in the abstracts in appliedlinguistics discipline.

The proportion of self-mention is low in all the moves of the abstracts except PTR. This low frequency of self-mention in the abstracts, which shows the priority of object-centred rather than authorcentred orientation, is in line with Hyland and Jiang's (2017) report. They confirmed the shift to a less explicit authorial presence in applied linguistics RAs and showed the tendency to promote objectivity by avoiding the use of self-mention in this discipline.

This low frequency of self-mention is also consistent with Hyland and Jiang's (2016)findings, in indicatinga decline in using self-mention over a period of 50 years (1965-2015) in the field ofapplied linguisticsRAs and the increasing preferences for author-evacuated texts in this discipline. Thisshift from self-mentions to evidential in applied linguistics, which increases impersonality,is supported by Kawase's(2015) findings, in which authorial presence was reported to be reduced by avoiding the use of first person pronouns.

In the moves of RA abstracts, especially in STF, authors tend to use extrapositionrather than active voice by using it is argued that, andit is suggested that instead of using first person pronouns as a source of informationto distance themselves from the text (Hyland \& Jiang, 2017). Extraposition (Quirik et al., 1985) or "anticipatory it" (Hewings\&Hewings 2002) refers to the process by which the notional subject is moved or extraposed and allows authors to depersonalize their propositions and decrease human interventions.

On the other hand, the great use of self-mention in PTR can be explained by the authors' tendency to achieve visibility and the essentiality of achieving credit for authors (Hyland\& Jiang, 2018) during writing their hypothesis. This can be attributed to the authors' sense of responsibility towards their claims (Hyland \& Jiang, 2017).

Using engagement markers such as we and $u s$ in DTR, the authors of RA abstracts aimed to establish solidarity with their readers, while in STR and DTM they engage readers by asking them to perform an act via imperative verbs.This low frequency of engagement markers in the RA abstracts can be associated with Ozdemirand Longo's (2014) finding in which engagement markers were neitherobserved in the Turkish theses abstracts nor the American ones.

In sum, in line with Pho's (2008) findings, this study suggests that the authors in the RA abstractsof applied linguistics disciplineexplicitly showed their presence by using first person pronouns in PTR and employing hedges in STF and DTR. In addition, the most impersonal move in these abstracts is DTM due to the less frequent use of hedges, self-mention, and attitude markers.

\section{Conclusions}

This study applied Pho's model as a framework in the analysis of the move structures in applied linguistics RA abstracts via the employment of Hyland's classification of metadiscoursemarkers to find answers for its RQs regarding opening move, closing move, move frequency, move sequence, move cycle, and move embedding, and also the distribution and functions of metadiscoures markers in each applied linguistics RAs abstract move. The findings of this study showed that nearly $86 \%$ of the RA abstracts encompass three obligatory moves (PTR, DTM, and STF) identified by Pho (2008). In addition, PTR and STR were identified as opening move and DTR, STF, and DTM were found as closing move. Regarding the use of metadiscourse markers, interactive devices were used more commonly than 
interactional ones. The findings of thecurrent study have some possible pedagogical implications. For instance, the results of the move analysis enable academic writers in applied linguistics disciplineto increase their awareness of the structure of abstracts in terms of the functions of the metadiscouse markers in RA abstracts.Another implication can be related to the development of EAP materials, for instanceauthors of EAP books, inspired by these findings, can focus on how different moves of abstracts should be written regarding their frequency and sequence and also how these markers and their relevance to abstract moves can be taught in academic writing courses through explicit teaching of these structures (Mu et al., 2015). Concerning the integration of move analysis and distribution of metadiscourse markers, the findings can also have implications for novice writers, especially those students who recently enter the academic world as academic members of the community of applied linguistics and aim to be active members in this community bypublishing their articles in high-impact factor journals. The findings of this study inform them how to use specific metadiscourse markers properly in each move.

Regarding the limitations of this study, one of these limitations is related to the number of articles analyzed in this study. This small scale of the dataset in the present study might underminethe generalizability of the findings.A further limitation may be attributed to the restrictionof thedata to applied linguistics discipline, which is representative of soft sciences.Researchers, for further investigations on metadiscourse markers in move structure, can explore the schematic structure of RA abstracts in other, hard or soft science, disciplines.In addition, drawing inferences only from written texts would be difficult; thus, interviewing authors of the RA abstracts can be helpful for providing deeper insights into the aims of the present study. With this in mind, one of the limitations of the present research lies in absence of interviewees.Finally, larger corpora of this kind need to be collected to integrate the analysis of rhetorical moves and metadiscourse markers not only in RA abstracts but also in other different sections of RAs.

\section{Ethics Committee Approval}

The author(s) confirm(s) that the study does not need ethics committee approval according to the research integrity rules in their country (Date of Confirmation: December 11, 2020).

\section{References}

Adel, A. (2016). Remember that your reader cannot read your mind: Problem/solution-oriented metadiscourse in teacher feedback on student writing. Journal of English for Specific Purposes, 45, 54-68.

Biber, D., Connor, U., \& Upton, T. (2007) Discourse on the move: Using corpus analysis todescribed/iscourse structure. Amsterdam: John Benjamins.

Can, S., Karabacak, E., \&Qin, J. (2016). Structure of moves in RA abstracts in Applied Linguistics. Publications, 4(3), 23-39

Chan, T. (2015). A corpus-based study of the expression of stance in dissertation acknowledgements. Journal of English for Academic Purposes, 20, 176-191.

Crosthwaite, P., Cheung, L., \& Jiang, K. (2017). Writing with attitude: Stance expression in learner and professional dentistry research reports. Journal of English for Specific Purposes, 46, 107-123. 
Flowerdew, J. (2008). Scholarly writers who use English as an additional language: What can Goffman's "Stigma" tell us? Journal of English for Academic Purposes,7(2),77-86.

Friginal, E., \&Mustafa, S. (2017). A comparison of U.S.-based and Iraqi English research article abstracts using corpora. Journal of English for Sspecific Purposes, 25, 45-57.

Gillaerts, P.,\& Van de Velde, F. (2010) "Interactional metadiscourse in research article abstracts", Journal of English for Academic Purposes, 9, 128-139.

Halliday, M. A. K. (1994). An introduction to functional grammar. London: Edward Arnold.

Hewings, M., \&Hewings, A. (2002).It is interesting to note that...": a comparative study of anticipatory 'it' in student and published writing. Journal of English for Specific Purposes, 21(4), 367-383.

Holmes, R. (1997). Genre analysis and the social sciences: an investigation of the structure of research article discussion sections in three disciplines. Journal of English for Specific Purposes, 16(4), 321337.

Ho, V., \& Li, C. (2018). The use of metadiscourse and persuasion: An analysis of first year university students' timed argumentative essays. Journal of English for Academic Purposes,33, 53-68.

Huckin, T. (2001). Abstracting from abstracts.Academic writing in context: Implications and applications. London: Continuum.

Hu, G.,\& Cao, F. (2011) Hedging and boosting in abstracts of applied linguistics articles: A comparative study of English- and Chinese-medium journals. Journal of Pragmatics, 43, 2795-2809.

Hyland, K. (2001). Humble servants of the discipline? Self-mention in research articles. English for Specific Purposes, 20, 207-226.

Hyland, K. (2004). Discplinary discourses. Ann Arbor.Michigan: University of Michigan Press.

Hyland, K., \& Jiang, F. (2017). "We believe that": changes in an academic stance marker. Australian Journal of Linguistics. 38 (2). 139-161.

Hyland, K., \& Jiang, F. (2018). "In this paper we suggest": changing patterns of disciplinary metadiscourse. Journal of English for specific purposes,51, 18-30.

Hyland, K. (2005). Metadiscourse. London, UK: Continuum.

Hyland, K. (2007). Applying a gloss: Exemplifying and reformulating in academic discourse. Applied Linguistics, 28(2), 266-285.

Hyland, K., \& Jiang, F. (2016). Change of attitude? A diachronic study of stance. Written Communication, 33(3), 1-24.

Hyland, K., \&Tse, P. (2005). Hooking the reader: A corpus study of evaluative that in abstracts. Journal of English for Specific Purposes, 24(2), 123-139.

Hyland, K. (2009). Teaching and researching writing.Abingdon, UK: Routlege.

Jiang, F., \& Hyland, K. (2016). Metadiscursive nouns: Interaction and cohesion in abstract moves. Journal of English for Specific Purposes, 46,1-14.

Kawase, T. (2015). Metadiscourse in the introductions of $\mathrm{PhD}$ theses and research articles. Journal of English for Academic Purposes, 20, 114-124.

Kawase, T. (2017). Rhetorical structure of the introductions of applied linguistics $\mathrm{PhD}$ theses. Journal of English for Academic Purposes, 31, 18-27. 
Khedri, M., Chan, S.,\& Ebrahimi, F. (2013). An exploration of interactive metadiscourse markers in academic research article abstracts in two disciplines. Discourse Studies, 15(3), 319-331.

Liu, Y., \& Buckingham, L. (2018). The schematic structure of discussion sections in applied linguistics and the distribution of metadiscourse markers. Journal of English for Academic Purposes, 34, $97-$ 109.

Lores, R. (2004). On RA abstracts: From rhetorical structure to thematic organization. English for Specific Purposes, 23, 280-302.

Mocanu, M. (2015). An empirical analysis of metadiscourse in the abstracts of Romanian accounting research articles. Accounting and Management Information System, 14(2), 362-377.

Mu, C., Jun, L., Ehrich, J., \& Hong, H. (2015). The use of metadiscourse for knowledge construction in Chinese and English research articles. Journal of English for Academic Purposes, 20, 135-148.

Miles, M. B., \& Huberman, A. M. (1994). Qualitative data analysis: An expanded sourcebook. Sage, Thousand Oaks, CA.

Ozdemir, N., \&Longo, B. (2014). Metadiscourse use in thesis abstracts: A cross-cultural study, Procedia - Social and Behavioral Sciences, 141, 59-63.

Pho, P.D. (2008) Research article abstracts in applied linguistics and educational technology: A study of linguistic realizations of rhetorical structure and authorial stance. Discourse Studies, 10(2), 231250 .

Quirk R., Greenbaum, S., Leech, G.\&Svartvik, J. (1985). Agrammar of contemporary English.Essex: Longman.

Samraj, B. (2008). A discourse analysis of master's theses across disciplines with a focus on introductions. Journal of English for Academic Purposes, 7, 55-67.

Santos,M. B. (1996). The textual organization of research paper abstracts in applied linguistics. TextInterdisciplinary Journal for the Study of Discourse, 16(4), 481-500.

Tanko, G. (2017). Literary research article abstracts: An analysis of rhetoricalmoves and their linguistic realizations. Journal of English for Academic Purposes, 27, 42-55.

Tseng, F. (2011). Analyses of Move Structure and Verb Tense of Research Article Abstracts in Applied Linguistics. International Journal of English Linguistics, 1(2), 27-39.

Upton, T., \& Cohen, M. (2009). An approach to corpus-based discourse analysis: The move analysis as example. Discourse Studies, 11(5), 585-605.

Yang, R., \& Allison, D. (2003). Research articles in applied linguistics: Moving from results to conclusions. English for Specific Purposes, 22, 365-385. 


\section{Meta söylem belirteçlerinin dağılımı ve işlevleri ışı̆̆ında uygulamalı dilbilim araştırma makalelerindeki özetlerin hareket yapısı}

\section{$\ddot{O} \mathbf{z}$}

Belirli bir alandaki diğer uzmanlarla iletişim kurmak ve akademik dünyada bilgi paylaşmak için, araştırmacıların araştırma makalelerini (RA) yüksek etkili faktör dergilerinde yayınlamaları gerekebilir. Ek olarak, RA'larını bu dergilerde yayınlama olasılığını artırmak için, yazma becerilerini geliştirmeleri gerekir. Şimdiye kadar RA'ların farklı bölümlerindeki meta söylem belirteçlerinin hareket yapısını veya dağılımını analiz eden birçok araştırma yapılmıştır. Ancak, bilgimiz dahilinde, uygulamalı dilbilimin RA özetlerinde hem hareket yapısının hem de üst söylem belirteçlerinin kullanımının analizini araştırmak için henüz bir çalışma yapılmamıştır. Bu boşluğu doldurmak için, mevcut çalışma, beş ana dergiden çıkarılan 125 RA özetini analiz etmek için RA'lardaki soyut hareketler modelini ve meta söylem belirteçleri modelini bir çerçeve olarak kullandı. Hareketin organizasyonel özellikleri ile ilgili olarak, araştırmanın sunulması (PTR) ve araştırmanın konumlandırılması (STR) açılış hamleleri olarak belirlenmiştir. Ayrıca, araştırmanın tartışılması (DTR), bulguların özetlenmesi (STF) ve metodolojinin (DTM) açıklanması kapanış hamleleri olarak kullanıldı. Ayrıca, toplanan özetlerde üst söylem belirteçlerinin dağılımına bakıldığında, bulgular geçişlerin yüksek sıklıkta olduğunu göstermiştir. Ek olarak, sonuçlar, uygulamalı dilbilim yazarlarının geçici olduğunu ve muhtemelen iddialarının zıt argümanlarına yer açmak için özetlerinde daha fazla çit kullandıklarını gösterdi. Son olarak, bu çalışma, uygulamalı dilbilim alanında acemi yazarlar için pedagojik çıkarımlar önermektedir.

Anahtar sözcükler: üst söylem belirteçleri; dağıtım; işlev; Pho'nun modeli; Hyland'ın modeli; RA özetleri; uygulamalı Dilbilim

\section{AUTHOR BIODATA}

Zahra Ashofteh works at University of Bojnord in Iran.

Majid Elahi Shirvan works at University of Bojnord in Iran.

Seyed Ehsan Golparvar works at University of Bojnord in Iran. 